\title{
Modeling and Evaluation of Innovative Activities in The Banking Services Sector
}

Huseynov A.F., Intellectual Property Agency of the Azerbaijan Republic Head of department Technology transfer and commercialization support” Baku, Azerbaijan, ahuseynov@copat.gov.az.

Özdemir YAHYA, Yalova University, Vocational School / Turkey, Computer Technology Department, Instructor, yahya.ozdemir56@gmail.com

ABSTRACT A new method for research the innovation processes in the service sector is suggested to provide a quantitative basis for measuring various aspects of innovation and to investigate a number of factors that may affect innovation in the banking services sector. Based on the conducted survey three separate components are calculated and further integrated into the Bank Innovation Index. Banks were compared on their innovative profiles (input, process, output) using the Spearman rank correlation.

Keywords: Innovation survey, Banking innovation, Integrated index, Spearman correlation, Ranking

\section{Bankacılık Hizmetleri Sektöründe Yenilikçi Faaliyetlerin Modellenmesi ve Değerlendirilmesi}

Öz

\begin{abstract}
Hizmet sektöründeki inovasyon süreçlerini araştırmak için yeni bir yöntemin, inovasyonun çeşitli yönlerini ölçmek ve bankacıllk hizmetleri sektöründeki yeniliği etkileyebilecek bir takım faktörleri araştırmak için nicel bir temel sağlaması önerilmektedir. Yapılan araştırmada üç ayrı bağımısız bileşen kullanılarak Banka İnovasyon Endeksi hesaplanmıştır. Bankaları Spearman reytingi korelasyonunu kullanarak yenilikçi profilleri (girdi, süreç, çıktı) ile karşılaştırıld.
\end{abstract}

Anahtar Kelimeler: Inovasyon anketi, Bankacilıkta inovasyon, Entegre endeks, Spearman korelasyonu, Siralaması

The pace of development and efficiency of the banking sector substantially depends on innovations. Assessment of innovations' level in the banking sector, influencing factors and also overcoming obstacles to the introduction of innovations are among the most pressing issues in this area. There is a number of articles ("6 Hottest Trends," 2017; Szirmai et al., 2009) devoted to new trends, as well as an assessment of influence of the introduced innovations on various aspects of bank's activities. There are also assessments of banks by international agencies, which determine the best innovative bank ("Global Banking," 2018) 
with the construction of a ranking of banks by countries (generally on the basis of expert estimates).

Constructing the integral innovative performance measure of bank based on the conducted innovative survey in the banking sector is a new method for research the bank's innovative and technological processes. It follows the objective to provide a quantitative basis for measuring various aspects of innovation and to investigate a number of factors that may affect innovation in the banking services sector.

The study consists of 2 consecutive parts:

1. An innovative survey was conducted in the banking sector (country level) using a methodology close to the accepted international format (Oslo Manual, 2018). The suggested method for calculating the bank's innovative characteristics offers the calculation of three separate components of banking innovations: input, activity, output. These components are integrated into Bank Innovation Index (BII).

2. In the second part on the basis of linear model using the method of rank correlations, the banks are ranked according to the values of this index and its components, the relationships between several parameters of banks' innovative activity are analyzed, the influence of input variables on the resulting estimates of banks' innovativeness are examined.

\section{Building a model of the bank's innovation activity}

\section{A. Data format and methodology}

According to accepted input-process-output model all innovative variables are divided into 3 sub-groups.

Table 1. Innovative input variables

\begin{tabular}{|c|c|c|c|}
\hline Variable & Definition & Scale & Range \\
\hline HT & $\begin{array}{l}\text { The personnel which have passed the } \\
\text { trainings }\end{array}$ & Numeric $(\%)$ & $0 ; 100$ \\
\hline $\mathrm{HS}$ & $\begin{array}{l}\text { The personnel working according its } \\
\text { specialty }\end{array}$ & Numeric $(\%)$ & $0 ; 100$ \\
\hline EL & Education level (masters and above) & Numeric $(\%)$ & $0 ; 100$ \\
\hline $\mathrm{EI}_{1} \div \mathrm{EI}_{6}$ & $\begin{array}{l}\text { Expenses on innovative activity (the } \\
\text { relative values) }\end{array}$ & Numeric $(\%)$ & $0 ; 100$ \\
\hline
\end{tabular}


Table 2. Innovative activity variables

\begin{tabular}{|c|l|l|l|}
\hline Variable & \multicolumn{1}{|c|}{ Definition } & Scale & Range \\
\hline $\begin{array}{c}\text { SI (NM, } \\
\text { NB) }\end{array}$ & $\begin{array}{l}\text { Service innovation (new to the } \\
\text { market, new for the bank) }\end{array}$ & $\begin{array}{l}\text { Binary trigger (with a } \\
\text { multiplier) }\end{array}$ & {$[0 \div 1]$} \\
\hline PI (SP, SD) & $\begin{array}{l}\text { Process innovation (providing } \\
\text { service or service distribution) }\end{array}$ & $\begin{array}{l}\text { Binary trigger (with a } \\
\text { multiplier) }\end{array}$ & {$[0 \div 1]$} \\
\hline $\begin{array}{c}\mathrm{MI}\left(\mathrm{MI}_{1},\right. \\
\left.\mathrm{MI}_{2}, \mathrm{MI}_{3}\right)\end{array}$ & $\begin{array}{l}\text { Marketing innovation }(\text { three } \\
\text { types of innovation) }\end{array}$ & $\begin{array}{l}\text { Binary trigger (with a } \\
\text { multiplier) }\end{array}$ & {$[0 \div 1]$} \\
\hline $\begin{array}{c}\mathrm{OI}\left(\mathrm{OI}_{1}, \mathrm{OI}_{2},\right. \\
\left.\mathrm{OI}_{3}\right)\end{array}$ & $\begin{array}{l}\text { Organizational innovation (three } \\
\text { types of innovation) }\end{array}$ & $\begin{array}{l}\text { Binary trigger (with a } \\
\text { multiplier) }\end{array}$ & {$[0 \div 1]$} \\
\hline $\begin{array}{c}\mathrm{CA} \quad(\mathrm{CW}, \\
\mathrm{CO})\end{array}$ & $\begin{array}{l}\text { The intensity of cooperation } \\
\text { (within the country, outside the } \\
\text { country) }\end{array}$ & $\begin{array}{l}\text { Numerical fractional } \\
\text { value) }\end{array}$ & {$[0 \div 1]$} \\
\hline $\begin{array}{c}\mathrm{OI}\left(\mathrm{BI}_{1} \div \mathrm{BI}_{6}\right) \\
\text { IU }\end{array}$ & $\begin{array}{l}\text { The significant obstacles (the } \\
\text { intensity) }\end{array}$ & $\begin{array}{l}\text { Numerical (fractional } \\
\text { value) }\end{array}$ & {$[0 \div 1]$} \\
\hline $\begin{array}{l}\text { The level of specific innovations' } \\
\text { use (intensity) }\end{array}$ & $\begin{array}{l}\text { Numerical (fractional } \\
\text { value) }\end{array}$ & {$[0 \div 1]$} \\
\hline $\begin{array}{l}\mathrm{CS} \\
\left(\mathrm{CS} \div \mathrm{CS}_{32}\right)\end{array}$ & $\begin{array}{l}\text { Creativity stimulation (four } \\
\text { methods) }\end{array}$ & $\begin{array}{l}\text { Binary trigger (with a } \\
\text { multiplier) }\end{array}$ & {$[0 \div 1]$} \\
\hline
\end{tabular}

Table 3. Innovative output variables

\begin{tabular}{|l|l|l|l|}
\hline Variable & \multicolumn{1}{|c|}{ Definition } & Scale & Range \\
\hline $\begin{array}{l}\text { SO (SM, } \\
\text { SB) }\end{array}$ & $\begin{array}{l}\text { Share of the provided services in total turnover (new } \\
\text { to the market, new for the bank) }\end{array}$ & $\begin{array}{l}\text { Numeric } \\
\mathbf{( \% )}\end{array}$ & $0 ; 100$ \\
\hline
\end{tabular}

All numerical variables $(0 ; 100)$ are converted into variables normalized to the interval $(0,1)$ :

$$
\frac{x^{i}-\min \left(x^{i}\right)}{\max \left(x^{i}\right)-\min \left(x^{i}\right)}
$$

The innovative characteristic of the bank BII (Innovation Index of Bank) is defined as a certain function of three components or the normalized sub-indices: the integral indicator of the input II_I (innovative resources and expenditures), the integral index of the activities II_A (innovation activity and influencing factors), the output indicator II_O (innovative results). The form of this function is determined from some a priori assumptions, in particular it can be additive with weight coefficients, it can be mixed additive-multiplicative, and so on.

$$
B I I=F\left(I I_{-} I, I I_{-} A, I_{-} O\right)(1)
$$




\section{B. Formulas for calculating the innovation index components}

In the formulas below, the subscript "n" means the normalization of the variables' values, the subscript "in" means the normalization of the values of the inverse indicator. Each sub-index represents the aggregation of several simple variables / indicators, measured within a single scale. The value of the composite indicator is obtained by weighted summation of the reference values.

Input component

$$
I I_{-} I=F_{1}(S P, E I)
$$

The II_I is the integral indicator of input, the names of the variables and their designations are given in Table 1.

$$
S P=\left(H T_{n}+H S_{n}+E L_{n}\right)
$$

HTn, HSn, ELn are characterizing the bank's staff potential that is very essential for the "diffusion" of innovation technologies; normalized numerical values are summed up forming a single estimated value.

$$
E I=\left(E I_{1 n}+E I_{2 n}+E I_{3 n}+E I_{4 n}+E I_{5 n}+E I_{6 n}\right)
$$

EI1n, EI2n, EI3n, EI4n, EI5n, EI6n - given to the bank turnover, normalized values of the numerical variables EI1 (own research and development), EI2 (outsourced research and development), EI3 (acquisition of equipment and software, EI4 (acquisition of external knowledge), EI5 (training in the development of innovation activities), EI6 (other activities).

Activity component

$$
I I_{-} A=F_{2}(I A, C A, O I, I U, C S)
$$

The II_A is the integral indicator of the types of innovation activity and additional factors; the names of variables and their designations are given in Table 2.

$I A=\left(N M * F_{1}+N B * F_{2}\right)_{\text {services }}+\left(S P * F_{3}+S D * F_{4}\right)_{\text {process }}+\left(M I_{1} * F_{5}+M I_{2} * F_{6}+\right.$ $\left.\mathrm{MI}_{3} * \mathrm{~F}_{7}\right)_{\text {marketing }}+\left(\mathrm{OI}_{1} * \mathrm{~F}_{8}+\mathrm{OI}_{2} * \mathrm{~F}_{9}+\mathrm{OI}_{3} * \mathrm{~F}_{10}\right)_{\text {organizational }}$

IA - innovation activity consists of 4 independent constituent units that reflect the availability and contribution of 4 types of innovations (service, process, marketing, organizational). Within each block, points are summed according to the values of the binary variables indicating the presence of the corresponding type of innovation, where for the 
types (sub-types) of innovations the corresponding weights F1 to F10 are introduced. The importance of each type of innovation is determined by experts (bank managers).

$$
C A=\left(C W_{n} * W_{1}+C O_{n} * W_{2}\right)
$$

$\mathrm{CA}$ is the intensity of cooperation activities, where the two calculated variables that characterize the innovative cooperation of the bank with partners inside the country and with foreign partners are combined. Used weights $\mathrm{W} 1$ and $\mathrm{W} 2$ are based on internal statistics.

$$
O I=\left(B I_{1} * V_{1}+B I_{2} * V_{2}+B I_{3} * V_{3}+B I_{4} * V_{4}+B I_{5} * V_{5}+B I_{6} * V_{6}\right)_{\text {in }}
$$

OI - obstacles to innovative activity are divided into 3 groups of barriers (cost, knowledge and market factors), each of which includes 2 separate types. Weights $\mathrm{V} 1 \div \mathrm{V} 6$ are calculated based on external information.

$$
I U=\left(I U_{1} * C_{1}+\cdots I U_{32} * C_{32}\right)_{n}
$$

IU - the intensity of innovation is essentially a latent variable, which reflects the so-called "objective" approach to innovation research. Weights $\mathrm{Ci}$ were determined by interviewing experts in the banking sector.

$$
C S=\left(C S_{1} * W_{1}+C S_{2} * W_{2}+C S_{3} * W_{3}+C S_{4} * W_{4}\right)
$$

CS - the stimulation of creative activity takes into account 4 independent types of activities, including financial support. CS1, CS2, CS3, CS4 - binary variables that determine the presence of a certain type of creative activity, and the corresponding factors W1, W2, W3, W4 - the expert weights assigned to these activities.

This last integral indicator plays the role of an "amplifier" of the main innovation processes and is used as a multiplicative coefficient to the expression (5).

Output component

$$
I I_{-} O=\left(S M * K_{1}+S B * K_{2}\right)_{n}
$$

The II_O - the integral indicator of innovative results is calculated as the percentage of total turnover from innovative services provided by the bank, with two types of services: new for the market and are new for the bank. Weights $\mathrm{K} 1$ and $\mathrm{K} 2$ are based on internal statistics.

Composite innovation index

The total innovative index of the bank (BII) is defined as:

$$
B I I=F\left(I I \_I+I I \_A+I I \_O\right)
$$


In the above expression, the sign "+" conditionally indicates the alleged additivity of the 3 components characterizing the bank's innovativeness.

The concept of a composite innovation index has been introduced in (Podlozhyonov I.M. et al., 2011; E. G. Garayannis et al., 2007). The BII could be used inside the bank to manage and optimize the innovation process, the innovativeness of the various components of the business could be analyzed, since the general expression can be broken down into separate sub-indexes (input, processes and output), and further down to single indicators. The BII can also serve as analysis tool for the whole banking sector: comparison and ranking, analysis of general factors contributing to the innovation performance of bank, etc.

This study does not offer the unified algorithm for calculating an integrated innovation index that would be used in all circumstances. There is an intention to demonstrate the importance of the IIB concept, and the question of identification of the appropriate combinations in a complex index is left as a subject for future research.

\section{The Results and Their Discussion}

The banks were ranked according to the IIB and several sub-indices, and Spearman rank correlation was calculated for every case. Several fundamental

Table 4. Correlation between BII and innovation activity variables ( $\mathrm{rs} \mathrm{kr}=\mathbf{0 . 3 3 6 )}$

\begin{tabular}{|c|c|c|c|c|c|c|c|c|}
\hline \multirow[b]{2}{*}{ BII } & \multicolumn{6}{|c|}{ Selected sub-indices/variables } & \multirow[b]{2}{*}{$\mathrm{r}_{\mathrm{s}}$} & \multirow{2}{*}{$\begin{array}{l}\text { Power of } \\
\text { relationship }\end{array}$} \\
\hline & $C A$ & OI & $B I_{1}, B I_{2}$ & $B I_{3}, B I_{4}$ & $B I_{5}, B I_{6}$ & $\dot{I U}$ & & \\
\hline+ & + & & & & & & 0.8077 & "very strong" \\
\hline+ & & + & & & & & 0.2838 & "weak" \\
\hline+ & & & + & & & & 0.4008 & "moderate" \\
\hline+ & & & & + & & & 0.1434 & "very weak" \\
\hline+ & & & & & + & & 0.3308 & "moderate" \\
\hline+ & & & & & & + & 0.6800 & "strong" \\
\hline
\end{tabular}

$\mathrm{rs} \mathrm{kr}=0.336$ for the number of entities $\mathrm{n}=25$, the level of significance $\mathrm{p}=0.05$ was adopted.

As a result, it was found that bank innovation index BII is strongly correlated with the intensity of cooperation activities of banks $(\mathrm{rs}=0.8077)$ and is weakly correlated with the obstacles/barriers to innovative activity ( $r s=0.2838$ ), but there is a moderate relationship with the sub-index of barriers, cost factors (lack of necessary financial resources, high cost of innovations). The rank correlation with the total intensity of innovations was also checked, the statistical relationship between them is strong $(\mathrm{rs}=0.68)$ and this indicates the fact that, in general, the concept of introducing IIB is productive. 
The top banks were compared on their innovative profiles (input, process, output). There was no monotony or superiority of any particular banks in all three profiles.

The analysis of input indicators was also has been carried out, which includes the personnel's structure of bank (the percentage of employees working in the specialty; having master's and higher degrees, staff trained on innovations), and the total expenses on innovative activity given to the bank turnover.

Table 5. Correlation between input innovation variables $(\mathrm{rs} \mathrm{kr}=\mathbf{0 . 3 3 6})$

\begin{tabular}{|c|c|c|c|c|c|c|c|}
\hline \multirow{2}{*}{ Combinations } & \multicolumn{9}{|c|}{ Selected sub-indices/variables } & \multirow{2}{*}{} & \multirow{2}{*}{$\begin{array}{c}\text { Power of } \\
\text { relationship }\end{array}$} \\
\cline { 2 - 7 } & $H T$ & $H S$ & $E L$ & $C S_{3}$ & $E I$ & $\mathrm{r}_{\text {s }}$ & "very weak" \\
\hline 1 & + & + & & & & -0.1746 & "very weak" \\
\hline 2 & + & & + & & & -0.00615 & "strong" \\
\hline 3 & + & & & + & & 0.6208 & "weak" \\
\hline 4 & + & & & & + & 0.3592 & "weak" \\
\hline 5 & & + & + & & & 0.2523 & "weak" \\
\hline 6 & & + & & + & & -0.2462 & "very weak" \\
\hline 7 & & + & & & + & -0.0681 & "very weak" \\
\hline 8 & & & + & + & & 0.1935 & "very weak" \\
\hline 9 & & & + & & + & -0.0323 & "very weak" \\
\hline 10 & & & & + & + & 0.1139 & \\
\hline
\end{tabular}

$\mathrm{rs} \mathrm{kr}=0.336$ for the number of entities $\mathrm{n}=25$, the level of significance $\mathrm{p}=0.05$ was adopted.

The input variables are poorly correlated with each other, only one strong link between the input variable HT (the personnel which have passed the training on innovation subjects) and the sub-index CS (the stimulation of creative activity, which includes the variable of creative training CS3) is revealed.

For the the banking sector belongs the main component determining the level of innovation of bank is II_A, that is, innovative transformations and the factors affecting them.

\section{REFERENCES}

6 Hottest Trends for Banking 2017 (n.d.). Retrieved from https://bankinnovation.net/2017/ 01/6- hottest-trends-for-banking-2017/

Adam Szirmai, Pierre Mohnen, Thanh le Phuoc, Research project "Innovation survey in Asian banking". United Nations University and Maastricht University (UNU-MERIT), Netherland, 2009.

Elias G. Garayannis and Mike Provance, "Measuring firm innovativeness: towards a composite innovation index built on firm innovative posture, propensity and performance attributes", June 2007. 
Global Banking \& Finance Review (n.d.). Retrieved from https://www .globalbankingandfinance.com/global-banking-finance-review-awards/

Oslo Manual (2018). Guidelines for Collecting, Reporting and Using Data on Innovation, 4th Edition, The Measurement of Scientific, Technological and Innovation Activities, OECD Publishing, Paris/Eurostat, Luxembourg.

Podlozhyonov Ilyya Mikhaylovich, Tsareva Viktoriya Mikhaylovna, Shiryaeva Yuliya Sergeevna "Improvement of Performance Evaluation of Innovation Activity in Commercial Banks" Published in «Creative Economy» № 12 / 2011 (in Russian).

\section{Appendix}

Spearman's correlation coefficient is a statistical measure of the strength of a monotonic relationship between paired data. It is denoted by rs and is constrained as follows

$1 \leq \mathrm{r} \_\mathrm{s} \leq+1$

And its interpretation is similar to that of Pearson's, e.g. the closer rs is to \pm 1 the stronger the monotonic relationship. When $\mathrm{rs}=+1$, there is a direct relationship between the two sequences, and when $\mathrm{rs}=-1$, there is an inverse relationship. We can describe the strength of the correlation using the following guide for the absolute value of rs:

$0.00 \leq \mid$ rs $\mid \leq 0.19$ "very weak"

$0.20 \leq|\mathrm{rs}| \leq 0.39$ "weak"

$0.40 \leq \mid$ rs $\mid \leq 0.59$ "moderate"

$0.60 \leq \mid$ rs $\mid \leq 0.79$ "strong"

$0.80 \leq \mid$ rs $\mid \leq 1.00$ "very strong" 